\title{
Twórcy zasad katalogowania w Polsce
}

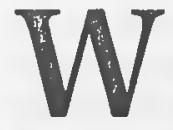

dobie postępującej komputeryzacji i międzynarodowego ujednolicania opracowywania zbiorów może warto pamiętać o tych, którzy dali początek tworzeniu zasad i instrukcji katalogowych w bibliotekach polskich. Iclea gromadzenia i udostępniania zbiorów dla potrzeb wszystkich obywateli została utrwalona w świaclomości społecznej przez braci Załuskich. Biblioteka Załuskich została oddana do użytku publicznego w 1747 r., Komisja Edukacji Narodowej uznała ją za główną książnicę Rzeczypospolitej ${ }^{1}$. W Polsce funkcjonowały wówczas biblioteki klasztorne, szkolne i akademickie, tworzyły one zamknięte, zdane tylko na siebie instytucje. Rzadko byly to biblioteki, najczęściej składnice książek, w których pracowali przypadkowi pracownicy. Reformy Komisji Edukacji Narodowej zmieniły tę sytuację o tyle, że zwrócono uwagę na stan bibliotek i uznano, że wpływają one na poziom umysłowy społeczeństwa. Dbanie o organizację bibliotek pojawiło się w planie rozwoju oświaty, nauki i kultury.

W 1783 r. pracę w Bibliotece Załuskich rozpoczął ksiądz pijar Onufry Kopczyński, który uporządkował zbiory według języków, a w obrębie każclego języka dzielił książki według pięciu wydziałów, a te $z$ kolei na podwydziały (dyscypliny). Wszystkie książki oznaczone byly sygnaturami zawierającymi nazwisko autora, skrócony tytuł dzieła oraz numer sali. Przyjęty system uporządkowania zbiorów był skomplikowany i pracochłonny. O. Kopczyński przystąpił równiez do sporządzania katalogów. Dla książek w jechnym języku przewidziany byl oddzielny katalog w postaci księgi. Każdy katalog sporządzony był w dwóch egzemplarzach, jeclen znajlowal się w bibliotece na stole i mogli z niego korzystać wszyscy użytkownicy. Był on podpisany przez prezesa Komisji Edukacji Narodowej. Drugi egzemplarz, podpisany przez bibliotekarzy pracujących w bibliotece, znajdował się w Archiwum Komisji Eclukacji Narodowej. Zakladano, że co dwanaście lat będzie sporząclzać się nowe katalogi zachowując równocześnie stare. Oprócz katalogu podstawowego w każclej szafie znajdował się „katalożek", który informował co się w niej znajduje.

Wypadki polityczne i kolejne rozbiory ziem polskich doprowadziły w $1794 \mathrm{r}$. do zawieszenia clzialalności Komisji Edulsacji Narodowej. W tymże roku zbiory Biblioteki Załuskich zostały wywiezione do Rosji.

W pracach XVIII-wiecznych bibliotekarzy można doszukiwać się wskazówek do tworzenia katalogów bibliotecznych, ale nie pojawiły się one w postaci instrukcji, więc nie stosowano ich konsekwentnie. Powstające katalogi były skomplikowane i mało użteczne. Zdecydowane zmiany przyniósł dopiero XIX w., w którym zaczęly powstawać różnorodne przepisy i obszerne instrukcje katalogowania alfabetycznego.

W Polsce kwestia katalogowania byla rozpatrywana w pracach wielu bibliotekarzy ${ }^{2}$. Większość nawiązywała do zasad stworzonych przez Joachima 
Lelewela w dziele Bibliograficznych ksiag dwoje ${ }^{3}$. Z problemami związanymi $z$ opracowaniem katalogów zetknął się on w czasie pracy w Bibliotece Publicznej przy Uniwersytecie Warszawskim. Lelewel opowiadał się za powszechnie stosowaną kolejnością prac w bibliotece: porządkowanie j ustawianie zbiorów według przyjętego systemu, opis dzieł na oddzielnych kartkach, nadanie sygnatury działowej, sporządzenie właściwego katalogu... Jako jeden $z$ pierwszych zwrócił uwagę na potrzebę istnienia $\mathrm{w}$ bibliotece katalogu alfabetycznego zbiorów. Katalogi takie dopiero zaczęły pojawiać się w bibliotekach, i to raczej w formie działowo - alfabetycznej. Według J. Lelewela opis katalogowy powinien być wierną kopią danych $z$ karty tytułowej dzieła $z$ zachowaniem ich formy i kolejności. Nawiązywał więc do wzorów i tradycji europejskich, do prac Friedricha Adolfa Eberta ${ }^{4}$ i Martina Schrettingera ${ }^{5}$. Hasłem opisu była dla niego przede wszystkim nazwa autora. Mogła być nim również nazwa tłumacza, komentatora, wydawcy, jeśli byli wymienieni na karcie tytułowej. W przypadlku jeżeli nazwisko autora nie było wymienione na karcie tytułowej, a w innym miejscu dzieła, hasłem był tytuł, a nazwisko autora otrzymywało odsyłacz. Początkowo J. Lelewel $z$ karty tytułowej przejmował również brzmienie nazwiska, później zaniechał tej praktyki, zalecał podawanie formy, przyjętej w literaturze i bibliografii.

W przypadku dzieł anonimowych przyjmował zasadę katalogowania ich pod tytułem. Hasłem był wówczas główny rzeczownik, główny wyraz tytułu lub pierwszy wyraz tytułu. Do hasła, którego wybór mógł nasuwać wątpliwości, zalecał sporządzać odsyłacze. W przepisach umieścił wiele przykładów, ilustrujących omawiane rozwiązania. Twierdził, że opis powinien zawierać ponadto informacje o: miejscu i roku wydania, drukarzu i nakładcy, formacie, tomach i woluminach, liczbie kart, tablic, cechach jednostkowych egzemplarza np. o oprawie. Dużo uwagi poświęcał J. Lelewel technice sporządzania kart katalogowych, omówil ich format, rubrykowanie. Zajmował się również alfabetem, pismem i pisownią stosowaną w katalogach.

Po omówieniu opisu na „cedułkach” głównych i niezbędnych odsyłaczach, przeszedł do szczególowych przepisów dotyczących sporządzania właściwego katalogu w formie księgi. Katalog w formie kar tkowej jeszcze nie funkcjonował. Opisy na „cedułkach” pomagały przy sporządzaniu katalogu, który nadal miał postać księgi.

Omówione przez Lelewela zasady zostały przejęte przez wielu bibliotekarzy. Powtarzał je w swojej pracy: O obowiązkach bibliotekarza Stanisław DuninBorkowski ${ }^{6}$. Przepisom katalogowania poświęca zasadniczo niewiele miejsca. Zaleca sporządzanie opisów na luźnych kartkach czerpiąc informacje $z$ karty tytułowej. Zakłada, że opis powinien zawierać dokładnie przepisany tytuł wraz z miejscem i rokiem druku, informacje o formacie, liczbie tomów, kolejności wydania. Do przepisów J. Lelewela nawiązywał również Franciszek Maksymilian Sobieszczański w artylkule: Bibliotekarstwo ${ }^{7}$. Sporządzanie katalogów uważał, za ważną czynność bibliotekarza. Za niezbędne uznał posiadanie przez bibliotekę katalogu alfabetycznego i rzeczowego, zalecał katalog repozytorialny (topograficzny).

Nie wyobrażał sobie biblioteki bez katalogów Władysław Górski: „po ich dopiero wykończeniu księgozbiór w zupełności zasługuje na nazwę biblioteki" ${ }^{8}$. 
Uważal, że przy tworzeniu katalogów należy stosować ustalone przepisy, a nie dowolne, indywidualne teorie. W swojej pracy często cytuje F. M. Sobieszczańskiego, rzadko J. Lelewela.

Najpełniejszą instrukcję opisu katalogowego stworzył Karol Estreicher. Twórca Bibliografii polskiej musial stosować ścisłe reguły opisu wydawnictw. W 1863 r. objął stanowisko bibliotekarza w Bibliotece Głównej, zajął się opracowaniem zbiorów tej biblioteli. Istniały w niej katalogi książek polskich i obcych, ale K. Estreicher ocenił je bardzo negatywnie. Przystępując do prac katalogowych sporządził instrukcję, której oryginał nie zachował się niestety do naszych czasów. Swoje poglądy na temat katalogów i katalogowania przedstawił również w artykule Katalog ${ }^{9}$. Omówił w nim rodzaje katalogów, ich formę i „istotę”. Uważał, że biblioteka powinna mieć co najmniej trzy katalogi: alfabetyczny, systematyczny, przedmiotowy. Spośród tych katalogów wyróżnił katalog alfabetyczny, który powinien być, według niego, najdokładniejszy, zawierający pełny opis wydawnictw.

Opis katalogowy powinien zawierać: imię i nazwisko autora wraz z określeniem jego zawodu, odpis tytułu bez opuszczeń, przy dziełach wielotomowych tytuły tomów, ilość stron, tablic, informację o kolejnym wydaniu, formacie, miejscu i roku druku, dedykacjach, miejscu składu. Za bardzo ważny element opisu uważał nazwisko autora, żądał poszukiwania autorstwa i opisywania dzieł anonimowych pod ustalonym nazwiskiem. W opisie katalogowym zalecał umieszczania symbolu klasyfikacji i oznaczenia miejsca przechowywania, oraz informacji o cechach indywidualnych danego egzemplarza np. oprawie, zapiskach rękopiśmiennych itp. Uważał równiez, że obok informacji bibliograficznych powinny znaleźć się informacje o sposobie nabycia i cenie. Ciekawostką może być to, że domagał się informacji o wydawnictwach związanych $z$ danym dziełem np. o recenzjach. Podstawę opisu stanowil cały dokument, a opis do katalogu sporządzany miał być $z$ autopsji.

W swym artykule umieścil wzór karty katalogowej. Jest ona podzielona na rubryki, miało to pomóc w zachowaniu konsekwencji opisu i zapewnić jednolitą formę. Proponuje porządkowanie kart katalogowych w formie jakby ksiązeczek, co miało zastąpić katalog książkowy, ale wymagało przewidzenia ilości wykorzystanych kart katalogowych.

II Rzeczypospolita (1918-1939) to okres organizowania się państwa polskiego, równiez bibliotek. Edward Kuntze w swoim artykule „Potrzeby polskich bibliotek naukowych" ${ }^{10}$ omówil stan bibliotek i wskazał sprawy, które powinny zostać szybko rozwiązane, m.in. widział potrzebę ustanowienia i wprowadzenia jednolitych przepisów katalogowania, które obowiązywałyby we wszystkich polskich bibliotekach. To zapoczątkowalo prace bibliotekarzy nad ujednolicaniem zasad katalogowania alfabetycznego.

W 1923 r. wydlano projekt Związku Bibliotekarzy Polskich pt. Przepisy katalogowania alfabetycznego $\mathrm{w}$ bibliotekach polskich ${ }^{11}$. Prace nad jego opracowaniem trwały od 1917 r. Edward Chwalewik, prezes Związlku Bibliotekarzy Polskich, we wstępie do Przepisów stwierdzil, że do ich wydania skłoniły Związek przede wszystkim dwa względy: „nader pilna potrzeba ułatwienia pracy nad katalogowaniem książek wielu powstającym w kraju bibliotekom publicznym oraz gorące pragnienie przyczynienia się $w$ ten sposób do wszczęcia fachowej 
na ten temat dyskusji w szerokich kołach bibliotekarzy i do ujednolicenia metody katalogowania książek we wszystkich polskich bibliotekach". Bibliotekarze tworząc ten projekt analizowali instrukcje zagraniczne: francuską, pruską, anglo-amerykańską i belgijską (Międzynarodowego Instytutu Bibliograficznego w Brukseli).

Instrukcja opracowana przez ZBP zawierała tylko podstawowe zasady katalogowania. Odnajdujemy w niej definicję katalogu alfabetycznego, zasady jego sporządzania, informacje o typach kart katalogowych i sposobach ich redagowania.

Przepisy katalogowania alfabetycznego ZBP nie były jedyną instrukcją wydaną w latach dwudziestych. Prace nad ujednoliceniem zasad katalogowania były prowadzone równiez w Bibliotece Uniwersytetu we Lwowie. Rudolf Kotula, clyrektor tej biblioteki, opracował instrukcję katalogowania alfabetycznego wydaną w $1924 \mathrm{r}^{12}$. Instrukcja R. Kotuli była adaptacją pruskich przepisów katalogowania dla potrzeb bibliotekarzy polskich, uwzglęclniała także tradycje katalogowania Biblioteki Uniwersyteckiej we Lwowie i Biblioteki Jagiellońskiej.

Na wstępie instrukcji lwowskiej R. Kotula ustalił, że podstawą opisu miało być samo dzieło. Podał delinicję jednostki katalogowej, omówił elementy uwzglęclniane w opisie (tytuł, objętość, format, adres wydlawniczy, nalkładca i clodatki do dzieła głównego) oraz terminy spotykane przy pracy katalogowej. W dalszej części omówił hasła oraz zasady szeregowania kart w katiłlogu. Lwowska instrukcja była szczegółowa i wyczerpująca.

Marian Łodyński, zajmując się bibliotekami wojskowymi, w 1926 r. stworzył instrukcję mającą unormować zasady katalogowania książek i wydawnictw periodycznych dla tych placówek ${ }^{13}$. W liście ${ }^{14}$ do Adama Łysakowskiego M. Łodyński pisał, że lunclusze nie pozwoliły mu wydać drukiem instrukcji, ale aby nie orlwlekać sprawy wybił „domowym sposobem” 25 egzemplarzy na papierze bibułkowym. Twierdził, ze jest tam szereg odchyleń od Instrukcji R. Kotuli i od warszawskiej, a także szereg momentów nowych, dostosowanych do warunkow wojskowych, wnoszących do zagadnień bibliotekarskich pewne „novum”. Według tych przepisów podstawą opisu była karta tytułowa dzieła, ale M. Łodyński zalecał brakujące dane uzupełniać na podstawie innych części wydawnictwa, oraz innych źrócleł. Opis nazywał kopią karty tytułowej. W swojej pracy wyszczególnił również elementy opisu i hasła. Umieścił wiele przykładów opisu ilustrujących zawarte w instrukcji zasady.

W tym czasie powstały jeszcze dwa zbiory przepisów katalogowania alfabetycznego, ale żadnego $z$ nich nie wydano drukiem. Metoda katalogowania Biblioteki Uniwersyteckiej w Warszawie została ujęta w jednolity system i zapisana przez Waclawa Borowego. Podobnie uczynił Edward Kuntze w Biblistece Jagiellońskiej.

Józef Grycz był zainteresowany powstaniem ogólnopolskiej instrukcji katalogowania.W liście do A. Łysakowskiego pisał ${ }^{15}$, ze za najkorzystniejszą drogę ustanowienia ogólnopolskiej instrukcji uważa ankietę. Twierdził, iż projekt powinno opracować jedno środowisko i rozesłać w odbitkach maszynowych do bibliotek, które zaproponują odpowiednie zmiany. Te $z$ kolei rozpatrzą autorzy projektu, ewentualnie je uwzględnią i znów prześlą bibliotekom. Po ponownych poprawkach dokona się ostatecznej redakcji, którą zatwierdzi ministerstwo i za- 
prowadzi mocą clekretu lub rozporządzenia. Tak J. Grycz widział etapy powstawania ogólnopolskiej instrukcji katalogowania alfabetycznego. Dokonał on porównania pięciu instrukcji katalogowania spotykanych $w$ Polsce ${ }^{16}$. Zauważyl, że większość jednakowo normuje pracę katalogującego. Wskazał na niejasność m.in. w kwestiach: wyboru hasła, wyboru słów $z$ tytułu, traktowaniu nazwisk $\mathrm{i}$ imion, układaniu kart w katalogach. Po przeanalizowaniu istniejących między nimi różnic i podobieństw J. Grycz doszedł do wniosku, że żadna $z$ nich nie może stać się instrukcją ogólnokrajową. Uważał, że powinna powstać nowa przez połączenie najsłuszniejszych zasad stosowanych w poszczególnych bibliotekach oraz niektórych przepisów zagranicznych. W podobny sposób jak przepisy krajowe J. Grycz przeanalizował instrukcje katalogowania obowiązujące w innych krajach: pruską, anglo-amerykańską, rrancuską, włoską i czeską ${ }^{17}$.

Na II Zjazd Bibliofilów wydano drukiem referat Waclawa Borowego: Prolegomena do wszelkiej przyszłej instrukcji katalogowania ${ }^{18}$, autor zawarł w nim wytyczne dla instrukcji. Miały ona mieć przejrzysty układ i wyraźnie definiować używane terminy. Instrukcja powinna według niego odznaczać się poprawnością języlkową, trafnością doboru terminów, jasnością stylizacji (niezawiłymi zdaniami), dokładnością sformułowań (nie powinny to być zasady wymagające (luzych wyjątków). Powinna zawierać trafne przykłady. W. Borowy był jrzeciwnikiem opracowania przepisów ogólnopolskich. Uważał, że krajowa unifikacja katalogowania jest tylko pięknie brzmiącym, ale mało treściwym hasłem. Twierdził, że należy zająć się ustaleniem zasad katalogowania w obrębie poszczególnych bibliotek.

W wyniku dyskusji II Zjazd Bibliolilów Polskich uchwalił wniosek skierowany do Wydziału Bibliotek Państwowych Ministerstwa Wyznań Religijnych i Oświecenia Publicznego wzywający do opracowania instrukcji ogólnopolskiej. Był to początek żmudnej drogi w kierunku polskiej instrukcji alfabetycznego katalogowania zbiorów.

Na zlecenie MWRiOP J. Grycz opracował Zasadnicze wytyczne polskich przepisów katalogowania, które w 1927 r. zostały zaakceptowane przez Wydział Bibliotek Państwowych. W tym samym czasie rozesłano je do zaopiniowania do największych bibliotek państwowych i niepaństwowych. Na I Zjeździe Bibliotekarzy Polskich (Lwów 1928 r.) J. Grycz wygłosił referat pt. Ogólnopolska ins trukcja dla sporządzania alfabetycznych katalogów bibliotecznych. W pracach nad instrukcją wzięło udział 13 bibliotek naukowych. Do czerwca 1930 r. nadesłały one własne propozycje, które stanowiły materiał do opracowania przez J. Grycza pierwszego projektu Przepisów katalogowania w bibliotekach polskich.

Projekt rozesłany bibliotekom wywołał szereg kontrowersji. M. Łodyński zarzucał mu to, że jest pełen latynizmów i uważal, że należałoby go spolszczyć ${ }^{19}$. A. Łysakowskiemu nie podobało się wprowadzenie autorstwa korporatynego, które uważał za zbędne. Twierdził, że J. Grycz wprowadził fikcyjne hasła, które nic nie upraszczają. Zarzucał, że autor nic nie wie o Urzędowym Wykazie Druków oraz nie zna katalogu przedmiotowego. Krytykował również redakcję projektu twierdząc, ze zawiera dużo wewnętrznych sprzeczności ${ }^{20}$.

Opinie, które biblioteki nadesłały J. Gryczowi posłuzyły mu do korekty projektu i stworzenia nowej wersji Instrukcji. Skarżył się, że opracowanie ankiet 
jest straszną pracą, że musi pójść na ustępstwa. Instrukcję nazywał „projektem kompronisów". Wybierał pomiędzy różnymi rozwiązaniani proponowanymi przez bibliotekarzy z Wilna, Lwowa, Krakowa i Warszawy. Było to tym trudniejsze, że każda ze stron swoje rozwiązania uważała za najsłuszniejsze. Przy dużych rozbieżnościach tworzył tablice najważniejszych odchyleń od Instrukcji.

Prace nad drugą wersją projektu trwały do 1 lipca $1931 \mathrm{r}$. W październiku następnego roku powstała trzecia wersja projektu. Każda $z$ nich była rozsvłana przez MWRiOP do bibliotek, które wyrażały swe krytyczne opinie. Uwagi nadsyłane przez biblioteki J. Grycz wykorzystywał przy redakcji następnej wersji przypisów. Skarzył się często na współpracę z bibliotekami. Narzekał, że nie przysyłają opinii na czas, że nie może zabrać się do pracy nie mając wszystkich ankiet. Autor uwzględniał opinie bibliotek, nanosił zmiany, które niszczyły przejrzystą konstrukcję i za każdym razem musiał ją od nowa redlagować. O pracach nad instrukcją informował bibliotekarzy. Na III Zjeździe Bibliotekarzy Polskich wygłosił referat: Na drodze do polskich instrukcji alfabetycznego katalogowani. Ostatnia wersja instrukcji ${ }^{21}$ została zatwierdzona przez MWRiOP jako obowiązująca w państwowych bibliotekach naukowych całego kraju od 1 czerwca $1934 \mathrm{r}$.

Po ukończeniu prac J. Grycz wyraził krytykę przyjętej metody ankietyzacji, która bardzo przedłużyła prace nad instrukcją. Uważał, że dużo lepszym rozwiązaniem byłoby powołanie 2-3 osobowej komisji i nie uwzględnianie opinii środowiska bibliotekarskiego, a odpowiedzialność ponieśliby wtedy twórcy.

Ostateczna wersja instrukcji nie zdobyła całkowitego poparcia bibliotekarzy. J. Grycz wiedział o tym, ale zclawał sobie sprawę, że w tej kwestii wszystkich nie zaclowoli.

W części wstępnej przepisów J. Grycz podał definicję katalogu, określił jego zadania i funkcje. Ustalił, że jednostką katalogową powinien być egzemplarz druku odrębnego bibliograficznie i typograficznie, który pod względem piśmienniczym i wydawniczym jest samoistną całością. Omówił dokładnie rodzaje opisów katalogowych (główne i pomocnicze) oraz ich części składowe i funkcje. W dalszej części podał szczegółowe zasady opisu wydawnictwa. Omawiał wszystkie jego elementy od wyboru hasła, aż do adresu wyclawniczego i uwag bibliograficznych.

Przepisy katalogowania w bibliotekach polskich. I Alfabetyczny katalog druków. Była to pierwsza w Polsce instrukcja katalogowania. Do wybuchu II wojny światowej wytyczne nie zostały do końca wprowadzone w praktyce bibliotekarskiej.

Przedwojenny wysiłek J. Grycza nie poszedł na marne, w 1946 r. ulkazało się pierwsze wydanie Skróconych przepisów katalogowania alfabetycznego ${ }^{22}$. Autor był przekonany o konieczności istnienia dwóch instrukcji katalogowych, dla bibliotek naukowych oraz dla bibliotek mniejszych.

W styczniu 1948 r. ukazało się drugie wydlanie Skróconych przepisów. Przy ich redagowaniu J. Gryczowi pomagala Wladyslawa Borkowska. Autorzy bardzo ostrożnie wprowadzali zmiany. Za ważniejsze niż tworzenie idealnegc katalogu, przez ciągłe ulepszanie przepisów jego opracowywania, uznali trzymanie się jednolitych zasad katalogowania. Mimo że za każdym następnym wydaniem zapowiadano ukazanie się „dużych" przepisów katalogowania doczelkaliśmy się sześciu wznowień $(1946,1448,1960,1969,1975)$. Spowodowane to bylo wy- 
czerpaniem nakładów poprzedniego wydania, ale również ciągłym zapotrzebowaniem na podrecznik do szkolenia nowej kadry.

W Skróconych przepisach ${ }^{23} \mathrm{~J}$. Grycz i W. Borkowska omówili wszystkie zasady katalogowania: budlowę katalogu, dobór i formułowanie haseł oraz opis bibliograficzny. Funkcjonowały one w Polsce ponad 40 lat. Przez tak długi okres posługiwano się nimi przy wyborze haseł. $Z$ czasem rozwiązania krajowe zostały wyparte przez zalecenia międzynarodowe, które stały się podstawą krajowych instrukcji katalogowania, a katalogi tradycyjne coraz częściej wypierane są przez katalogi komputerowe ${ }^{24}$.

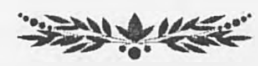

\section{Przypisy:}

B. Szyndler, Biblioteka Zahuskich, Wroclaw 1983, s. 47.

${ }^{2}$ Pierwsze polskie instrukcje katalogowania omówiła w swym artykule Krystyna Pieńkowska. K. Pieńkowska, Polskie instrukcje katalogowania od XIX do polowy XX wieku, ,Przegląd Biblioteczny" 1971, R. 39, z. 1-4, s. 258 - 279.

${ }^{3}$ J. Lelewel, Bibliograficznych ksiag dwoje, Wilno 1823-1826.

${ }^{4}$ F. A. Ebert (1791-1834) - bibliotekarz i bibliograf niemiecki. Byl prekursorem samodzielności zawodu billiotekarskiego i propagatorem publicznego udostępniania zbiorów. Wydał prace, w których omawial zadania biblioteki, bibliotekarza i bibliografii.

${ }^{5} \mathrm{M}$. Schrettinger - bibliotekarz niemiecki, po studiach teologicznych byl bibliotekarzem w macierzystym klasztorze w Weisenole (Bawaria). Po sekularyzacji zakonu przeszedl do służly w Bibliotece Nadwornej w Monachiım. Najwięcej uwagi poświęcal ustawianiu zbiorów, krytyce katalogów systematycznych i opracowaniu katalogu przedmiotowego (jednego $z$ pierwszych $w$ Europie). Jego koncepcje wyprzedziły współczesnych $\mathrm{i}$ utorowaly bibliotekoznawstwu miejsce wśród kierunków uniwersyteckich w XX w. Proponował $\mathrm{m}$. in. aby hasło opisu formułowane było w języku narodowym, a nie jak dotychczas - po lacinie.

${ }^{6} \mathrm{~S}$. Dumin-Borkowski, O obowiązkach bibliotekarza, Lwów 1829.

${ }^{7}$ Encyklopedia Powszechna Orgelbranda, t. 3, Warszawa 1866, s. 440-454.

${ }^{8}$ W. Górski, Krótki rys zasad bibliotekoznawstwa, Warszawa 1863, s. 63.

${ }^{9}$ Encyklopedia Powszechna Orgelbranda, t. 14, Warszawa 1863, s. 372-404.

${ }^{10}$ E. Kuntze, Potrzeby polskich bibliotek naukowych, „Nauka Polska”, t. 2, 1919, s. 503-542.

${ }^{11}$ Przepisy katalogowania alfabetycznego w bibliotekach polskich. Projekt., Warszawa 1923.

${ }^{12}$ R. Kotula, Instrukcja o katalogach alfabetycznych bibliotek naukowych, Lwów 1924.

${ }^{13}$ M. Łodyński, Instrukcja dla kierowników bibliotek wojskowych, Warszawa 1926.

${ }^{14}$ Bibliotekarstwo polskie 1925-1951 w świetle korespondencji jego współtwórców, Warszawa 1995, s. 22-23.

${ }^{15}$ Ibidem, s. 203.

${ }^{16} \mathrm{~J}$. Grycz, Porównanie polskich przepisów katalogowania, Kraków 1926. 
${ }^{17}$ J. Grycz, Porównanie zagranicznych przepisów katalogowania, Kraków 1929.

${ }^{18}$ W. Borowy, Prolegonnena do wszelkiej przyszlej instrukcji katalogowania, Warszawa 1926.

${ }^{19}$ Ibidem, s. 42.

${ }^{20}$ Ibidem, s. 43-44.

${ }^{21}$ J. Grycz, Przepisy katalogowania w bibliotekach polskich. I alfabetyczny katalog druków, Warszawa 1934.

${ }^{22}$ J.Grycz, Skrócone przepisy katalogowania alfabetycznego, Warszawa 1946.

${ }^{23}$ Omówienia dokonano na podstawie wydania 6 (ostatniego).

${ }^{24}$ D. Grabowska, Katalogowanie alfabetyczne zbiorów bibliotecznych. Zarys problematyki, Warszawa 2003. 